Steven B. Backman MDCM PhD FRCPC,*

Reuben D. Stein PhD, ${ }^{\prime} \dagger$ David W. Blank MDCM FRCPC, $\ddagger$ Brian Collier PhD, $\S$ Canio Polosa MD PhD*†

\section{Different properties of the bradycardia pro- duced by neostigmine and edrophonium in the cat}

Purpose: The bradycardia produced by neostigmine and edrophonium was examined according to its relation to cholinesterase inhibition and to its sensitivity to block by muscarinic receptor antagonists. For comparison, the ability of muscárinic antagonists to block the bradycardia produced by electrical stimulation of the vagus nerve was determined.

Methods: Cats were anaesthetized, vagotomized and propranolol-treated. Heart rate was continuously recorded. Erythrocyte cholinesterase activity of arterial blood was measured using a radiometric technique. The right vagus nerve was isolated for electrical stimulation. The muscarinic antagonists used were atropine, glycopyrrolate, pancuronium, gallamine, and AFDX-1.16.

Results: Neostigmine produced a dose-dependent decrease in cholinesterase activity which reached a plateau at a cumulative dose of $0.16 \mathrm{mg} \cdot \mathrm{kg}^{-1}\left(E D_{50} 0.009 \pm 0.003 \mathrm{mg} \cdot \mathrm{kg}^{-1}\right)$. Neostigmine produced a dose-dependent decrease in heart rate with the dose-response relationship $\left(E D_{50} 0.1 \pm 0.01\right.$ $\mathrm{mg} \cdot \mathrm{kg}^{-1} ; P=0.0006$ ) shifted to the right of that for the inhibition of cholinesterase activity. In contrast to the anticholinesterase effect, the bradycardic effect did not reach a

\section{Key words}

ANTAGONISTS, NEUROMUSCULAR RELAXANTS:

edrophonium, neostigmine;

HEART: arrhythmia, bradycardia.

From the Department of Anaesthesia* and Division of

Clinical Biochemistry $\ddagger$, Royal Victoria Hospital, and Departments of Physiology† and Pharmacology $§$, McGill University.

Address correspondence to: Dr. S.B. Backman, Department of Anaesthesia, Royal Victoria Hospital, 687 Pine Ave. West,

Montreal, Quebec, Canada H3A 1A1.

This work was supported by grants from the Canadian Anaesthetists' Society and the Royal Victoria Hospital Research Institute to S.B.B. and from the Medical Research Council to B.C.

Accepted for publication 14 March, 1996. plateau and continued to increase even at doses at which the cholinesterase inhibition was maximal. The maximal decrease in heart rate when the heart was still in sinus rhythm was by $81 \pm 13$ bpm ( $49 \pm 7 \%$ of baseline), which was produced by a dose of $0.32 \mathrm{mg} \cdot \mathrm{kg}^{-1}$. Edrophonium produced dose-dependent decreases in cholinesterase activity and heart rate, which were highly correlated (correlation coefficient $r=0.99, P$ $<0.0001)$. The $E D_{50}$ of the reduction in heart rate $(0.9 \pm 0.18$ $\left.\mathrm{mg} \cdot \mathrm{kg}^{-1}\right)$ and cholinesterase activity (0.89 $\left.\pm 0.12 \mathrm{mg} \cdot \mathrm{kg}^{-1}\right)$ produced by edrophonium were similar. Moreover, the reduction in heart rate and cholinesterase activity produced by edrophonium reached a plateau at the same dose 16.4 $\left.\mathrm{mg} \cdot \mathrm{kg}^{-1}\right)$. At this dose, heart rate decreased by $22 \pm 2 \mathrm{bpm}$ (14.6 $\pm 0.9 \%$ of baseline). Compared to the bradycardia produced by stimulation of the vagus nerve, that produced by neostigmine was blocked by muscarinic antagonists at significantly lower doses while that produced by edrophonium was blocked at similar doses.

Conclusions: The neostigmine-induced bradycardia is poorly correlated with cholinesterase inhibition compared to that produced by edrophonium, and has a higher sensitivity to muscarinic receptor antagonists compared to that produced by edrophonium or vagus nerve stimulation. These results are consistent with the hypothesis that the neostigmine-induced bradycardia is, in part, the result of neostigmine directly activating cholinergic receptors within the cardiac parasympathetic pathway. The bradycardia produced by edrophonium may be accounted for solely by an anticholinesterase action.

Objectif: La bradycardie produite par la néostigmine et l'édrophonium fait l'objet de cette communication qui s'intéresse spécifiquement à sa correlation avec l'inhibition cholinestérasique et l'effet des antagonistes des récepteurs muscariniques. Pour fin de comparaison, l'influence des antagonistes muscariniques sur le blocage de la bradycardie induite par la stimulation électrique du nerf vague a été déterminée. Méthodes: Des chats étaient anesthésiés, vagotomisés et traités au propanolol. La fréquence cardiaque était enregistrée en continu. L'activité cholinestérasique érythrocytaire du sang artériel était mesurée par radiométrie. Le nerf vague 
droit était isolé pour la stimulation électrique. Les antagonistes muscariniques suivants étaient utilisés: l'atropine, le glycopyrrolate, le pancuronium, la gallamine et l'AFDX116.

Résultats: La néostigmine a produit une baisse: proportionnelle à la dose de l'activité cholinestérasique qui a atteint un plateau à la dose cumulative de $0 ; 16 \mathrm{mg} \cdot \mathrm{kg}^{-1}\left(E D_{50} 0,009 \pm\right.$ $\left.0,003 \mathrm{mg} \cdot \mathrm{kg}^{-1}\right)$. La néostigmine a provoqué une baisse proportionnèlle à la dose de la fréquence cardiaque avec une relation dose-effet $\left(E D_{50} 0,1 \pm 0,01 \mathrm{mg} \cdot \mathrm{kg}^{-1} ; P=0,0006\right)$ déviée à droite de celle de l'inhibition de l'activité cholinestérasique. Contrairement à l'effet anticholinestérasique, l'effet bradycardique n'a pas atteint de plateau et a continué d'aug. menter même aux doses d'inhibition cholinestérasique maximale. La baisse maximale dela fréquence cardiaque en rythme sinusal a été de $81 \pm 13 \mathrm{bpm}(49 \pm 7 \%$ de la ligne de base $)$ et a été induite par une dose de $0,32 \mathrm{mg} \cdot \mathrm{kg}^{-1}$. L'édrophonium a provoqué des baisses proportionnelles à la dose nettement corrélées de l'activité cholinestérasique et de la fréquence cardiaque, (coefficient de corrélation $r=0,99, P<0,0001$ ). $L ' E D_{s 0}$ de la baisse de fréquence cardiaque $(0,9 \pm 0,18$ $\left.\mathrm{mg} \cdot \mathrm{kg}^{-1}\right)$ et celle de l'activité cholinestérasique $(0,89 \pm 0,12$ $\mathrm{mg} \cdot \mathrm{kg}^{-1}$ ) produites par l'édrophonium étaient identiques. En outre, la baisse de la fréquence cardiaque et de l'activité cholinestérasique produite par l'édrophonium a atteint un plateau à une dose identique $\left(6,4 \mathrm{mg} \cdot \mathrm{kg}^{-1}\right)$. A cette dose, la fréquence cardiaque a diminué de $22 \pm 2 \mathrm{bpm}(14,6 \pm 0,9 \%$ de la ligne de base). Comparativement à la bradycardie produite par la stimulation vagale, la bradycardie produite par la néostigmine était bloquée par les antagonistes muscariniques à des doses plus faibles alors que celle produite par l'édrophonium était bloquée à des doses identiques.

Conclusions: La bradycardie induite par la néostigmine est en faible corrélation avec l'inhibition cholinestérasique comparativement à celle qui est produite par l'édrophonium, et est plus sensible aux antagonistes des récepteurs muscariniques comparativement à celle qui est produite par l'édrophonium ou la stimulation vagale. Ces résultats concordent avec l'hypothèse selon laquelle la bradycardie induite par la néostigmine est partiellement causée par l'activation directe de récepteurs cholinergiques empruntant la voie de conduction cardiaque parasympathique. La bradycardie produite par l'édrophonium peut s'expliquer uniquement par un effet anticholinestérasique.

A common side effect of anticholinesterase drugs is bradycardia, which, on occasion, can be so severe:as to result in asystole. ${ }^{1,2}$ A previous study suggested that the bradycardia induced by neostigmine involves mechanisms other than the inhibition of cholinesterase. ${ }^{3}$ In propranolol-treated, vagotomized cats neostigmine and edrophonium produced dose-dependent reductions in heart rate. However, the dose-response curves were markedly different for the two drugs. For neostigmine, throughout the range of doses tested, the magnitude of the bradycardia varied directly with dose and a plateau in the response was never observed. The decrease in heart rate produced by the highest dose of neostigmine used, while sinus rhythm was maintained, was approximately $50 \%$ of baseline. In contrast, edrophonium produced a dose-dependent decrease in heart rate to a plateau of only $15 \%$ below the baseline. The shape of the edrophonium dose-response curve was consistent with the expectation that, if the reduction in heart rate was the consequence of protection from hydrolysis of the acetylcholine ( $\mathrm{ACh}$ ) spontaneously released by the parasympathetic pre- and postganglionic terminals (Figure 1), a plateau in the response should occur, presumably at the dose which produces maximum inhibition of the enzyme. This prediction has never been tested. In contrast, the lack of a plateau in the neostigmine dose-response relationship suggests mechanisms additional to the inhibition of cholinesterase. On the basis of properties of the neostigmine-induced bradycardia we have suggested that neostigmine activates cholinergic receptors on cardiac parasympathetic ganglion cells, with subsequent release of $\mathrm{ACh}$ from their axon terminals at the sinus node ${ }^{3}$ (Figure 1). While the pharmacological identity of the cholinergic receptor(s) activated by neostigmine remains to be characterized, evidence suggests that it may be muscarinic of the $M_{2}$ sub-type. ${ }^{3,4}$

The purpose of this study was twofold. First, to determine how the anticholinesterase action of neostigmine and edrophonium is related to the production of the bradycardia, the relationship between the inhibition of cholinesterase and the decrease in heart rate was compared following administration of increasing doses of neostigmine or edrophonium. In a second set of experiments the potency of muscarinic antagonists to block the bradycardia produced by neostigmine or edrophonium, and electrical stimulation of the vagus nerve was compared. If neostigmine or edrophonium produces bradycardia solely by their anticholinesterase action, muscarinic antagonists should block the bradycardia produced by these drugs and that produced by vagus nerve stimulation at similar doses by interfering with the action of $\mathrm{ACh}$ (released spontaneously or by vagus nerve stimulation) at the SA node (Figure 1). If, on the other hand, neostigmine or edrophonium also activates muscarinic $\mathrm{M}_{2}$ receptors on cardiac ganglion cells, leading to subsequent release of $\mathrm{ACh}$ and activation of $\mathrm{M}_{2}$ receptors at the SA node, the bradycardia produced by these drugs may be more sensitive to muscarinic block, 


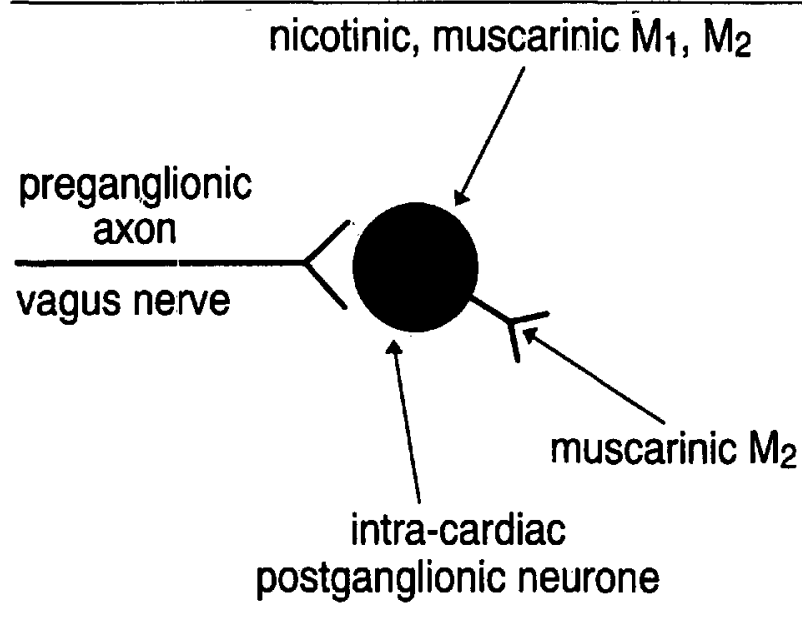

FIGURE 1 Schematic diagram of the peripheral cardiac parasympathetic pathway. Preganglionic axons contained in the vagus nerve synapse onto intra-cardiac postganglionic neurones, which in turn synapse onto cardiac parasympathetic target cells. ACh is released from both the preganglionic and postganglionic terminals. Cholinergic receptors have been identified on the postganglionic neurone as being nicotinic, muscarinic $\mathrm{M}_{1}$, and $\mathrm{M}_{2}{ }^{18}$ Cholinergic receptors on the target cells have been identified as being $M_{2}$.

compared to that produced by vagus nerve stimulation, because of an additive effect, resulting from an action of muscarinic block at both the cardiac ganglion cell and the SA node (Figure 1).

\section{Methods}

Cats (2.0-4.5 kg, $n=65)$ were anaesthetized with sodium pentobarbitone $\left(35 \mathrm{mg} \cdot \mathrm{kg}^{-1}\right.$ ip initial dose, maintenance doses $3-4 \mathrm{mg} \cdot \mathrm{kg}^{-1}$ iv every hour). Parasympathetic efferent nerve activity to the heart was interrupted by bilateral vagotomy (cervical level), and sympathetic transmission to the heart was blocked by propranolol ( 3 $\mathrm{mg} \cdot \mathrm{kg}^{-1} i v$ ), in order to avoid reflex changes in heart rate secondary to anticholinesterase administration. A constant infusion of $0.9 \% \mathrm{NaCl}$ solution: (7-8 $\mathrm{ml} \cdot \mathrm{kg}^{-1} \cdot \mathrm{hr}^{-1}$ ) and drugs were administered through a catheter in a femoral vein. A catheter was inserted in a femoral artery to withdraw blood samples for determination of erythrocyte cholinesterase activity (see below). Following tracheal cannulation, the cats were artificially respired with $100 \%$ oxygen. End-tidal $\mathrm{CO}_{2}$ was monitored and maintained at $30-35 \mathrm{mmHg}$. Core temperature was maintained at $37^{\circ} \mathrm{C}$ by a thermistor-controlled heating blanket. Arterial pressure was recorded on a Grass model 7 polygraph using a Statham transducer connected to a catheter in a second femoral artery. The arterial pressure pulse triggered a cardiotachometer for continuous recording: of heart rate. Lead II of the electrocardio- gram was continuously monitored on an oscilloscope to verify the presence of sinus activity following administration of anticholinesterases. The distal end of the cut right vagus nerve was separated from the sympathetic trunk and aortic depressor nerve and placed on a bipolar hook electrode connected via a Grass SIU5 stimulus isolation unit to a Grass S88 stimulator. The effect of cholinesterase inhibitors on erythrncyte cholinesterase activity was used as an index of their effect on activity in cardiac tissue. In this set of experiments, cholinesterase activity was determined on arterial blood samples prior to (control) and following injection of increasing doses of neostigmine or edrophonium, when heart rate had reached a steady-state at each dose. One hundred microlitre aliquots of freshly collected heparinized blood were pre-incubated with the butylcholinesterase inhibitor IS0-OMPA $\left(10 \mu \mathrm{M}, 22^{\circ} \mathrm{C}, 10\right.$ min) and acetylcholinesterase activity was measured with acetylcholine $(1.5 \mathrm{mM})$ as substrate. The ACh (acetyl labelled ${ }^{3} \mathrm{H}$ acetylcholine. $223 \mu \mathrm{Ci}$.. mmole ${ }^{-1}$ ) was added $(10 \mu \mathrm{l})$, the reaction proceeded $\left(22^{\circ} \mathrm{C}\right)$ for 60 sec, and was terminated by the addition of $1 \mathrm{ml}$ ice-cold isotonic buffer ( $\mathrm{pH} 7.4$ ) containing $1 \mathrm{mM}$ physostigmine. After centrifugation $(10,000 \mathrm{~g}$ for four minutes), the supernatant was collected and shaken with a solution (10 $\mathrm{mg} \cdot \mathrm{ml}^{-1}$ ) of tetraphenylboron in heptanone. Radioactivity in the organic phase (residual ${ }^{3} \mathrm{H}$ acetylcholine) and in the aqueous phase ( ${ }^{3} \mathrm{H}$ acetate resulting from the hydrolysis of substrate) were measured. The reversible inhibition of acetylcholinesterase by neostigmine and edrophonium and the need to ensure that the in vitro measures reflected the in vivo activity, required assay of cholinesterase activity without sample dilution. Each sample was measured in duplicate; assay variability was less than $5 \%$. The specificity of the assay was ensured by choice of substrate, $\mathrm{ACh}$, and by the use of IS0-OMPA so that acetylcholinesterase activity was measured. The sensitivity of the assay was determined by the specific radioactivity of substrate used; the hydrolysis of 1 nmole of $\mathrm{ACh}$ could be determined under the conditions used.

In another set of experiments the effect of muscarinic receptor antagonists on the bradycardia produced by anticholinesterases was tested using a dose of the anticholinesterases that produced $50-60 \%$ of the maximum decrease in heart rate. To this end, neostigmine 0.25 $\mathrm{mg} \cdot \mathrm{kg}^{-1}$ and edrophonium $1.0 \mathrm{mg} \cdot \mathrm{kg}^{-1}$ were administered, which produced reductions in baseline heart rate of $38 \pm 2 \%(n=24)$ and $10 \pm 1 \%(n=8)$, respectively. To study the effect of muscarinic receptor antagonists on the bradycardia produced by vagus nerve stimulation, the right vagus nerve was electrically stimulated 
$(10 \mathrm{~V}, 0.5 \mathrm{msec}, 1-2 \mathrm{~Hz}, 10 \mathrm{sec})$ to produce a reduction in heart rate of $34 \pm 1 \%(n=23)$. In this set of experiments, administration of neostigmine or edrophonium, and electrical stimulation of the vagus nerve, were done in different animals, and only one muscarinic antagonist was studied per animal. A dose-response relation was determined for each muscarinic receptor antagonist studied. The dose of the muscarinic receptor antagonist was increased once the response to the previous dose had reached a steady-state.

The relationship between dose and effect of either anticholinesterase drugs or muscarinic antagonists was determined by constructing dose-response curves. For each cat, the $\mathrm{ED}_{50}$ of the anticholinesterase or muscarinic receptor antagonist being studied was determined by linear regression analysis using the linear portion of the $\log$ dose-response curve (values between $20 \%$ and $80 \%$ of maximal effect). The $\mathrm{ED}_{50} \mathrm{~s}$ for anticholinesterase effects on heart rate and cholinesterase activity were compared using a paired Student's $t$ test. The $\mathrm{ED}_{50} \mathrm{~s}$ for muscarinic block of each type of bradycardia were compared using the unpaired Student's t test. A $P$ value of less than or equal to 0.05 was considered significant. Data are expressed as mean \pm SEM.

Non-selective muscarinic receptor antagonists used were atropine ${ }^{5}\left(\right.$ Sigma, $\left._{1}\right)$ and glycopyrrolate ${ }^{5}$ (Sabex Inc). The selective $M_{2}$ muscarinic receptor antagonists studied were 11,2-(Diethylamino)methyl-1-piperidinyl acetyl-5,11-dihydro-6H-pyrido 2,3-b 1,4 benzodiazepine-6-one $^{6}$ (AFDX-116, Boehringer Ingelheim), pancuronium $^{6}$ (Organon) and gallamine ${ }^{6}$ (RhonePoulenc Rorer). All drugs were dissolved in $0.9 \% \mathrm{NaCl}$ solution, with the exception of AFDX-116, which was dissolved in 10\% dimethyl sulfoxide (DMSO) in saline.

\section{Results}

Inhibition of cholinesterase activity and the bradycardia produced by edrophonium

Edrophonium produced a dose-dependent inhibition of cholinesterase activity ( $n=5$, Figures $2 \mathrm{~A}$ and $3 \mathrm{~A}$ ), which reached a plateau when a cumulative dose of 6.4 $\mathrm{mg} \cdot \mathrm{kg}^{-1}$ had been administered. At the plateau, cholinesterase activity was inhibited by $82 \pm 4 \%$. The estimated dose of edrophonium which produced $50 \%$ of the maximum inhibition was $0.89 \pm 0.12 \mathrm{mg} \cdot \mathrm{kg}^{-1}$. Edrophonium also produced a dose-dependent decrease in heart rate ( $n=5$, Figures $2 \mathrm{~B}$ and $3 \mathrm{~A}$ ) which closely paralleled the decrease in cholinesterase activity (correlation coefficient $\mathrm{r}=0.99, P<0.0001$ ) and reached a plateau at the dose at which inhibition of cholinesterase activity had reached saturation. The maximal decrease

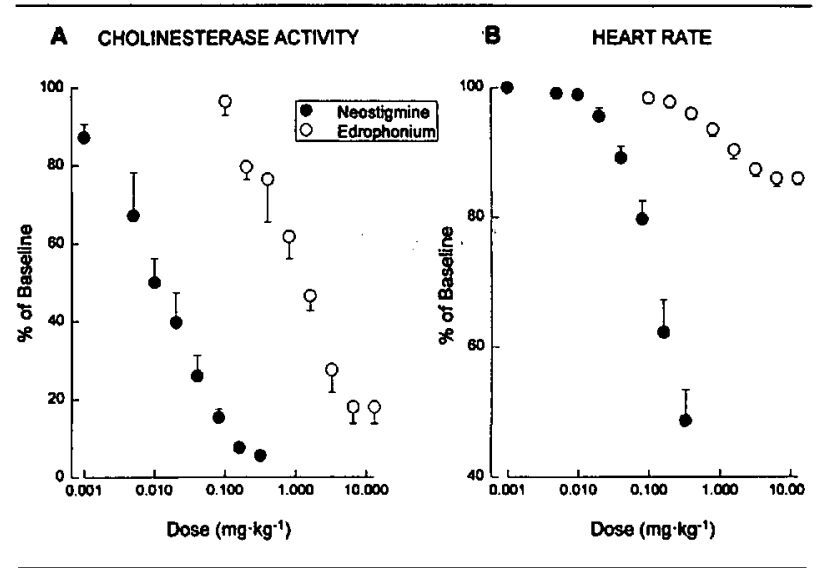

FIGURE 2 Relationship between the decrease in heart rate (panel A) or acetylcholinesterase activity (panel B) expressed as percent of baseline (ordinate) and dose of anticholinesterase (abscissa). Each point represents the average response in five animals. Bars indicate S.E.M.

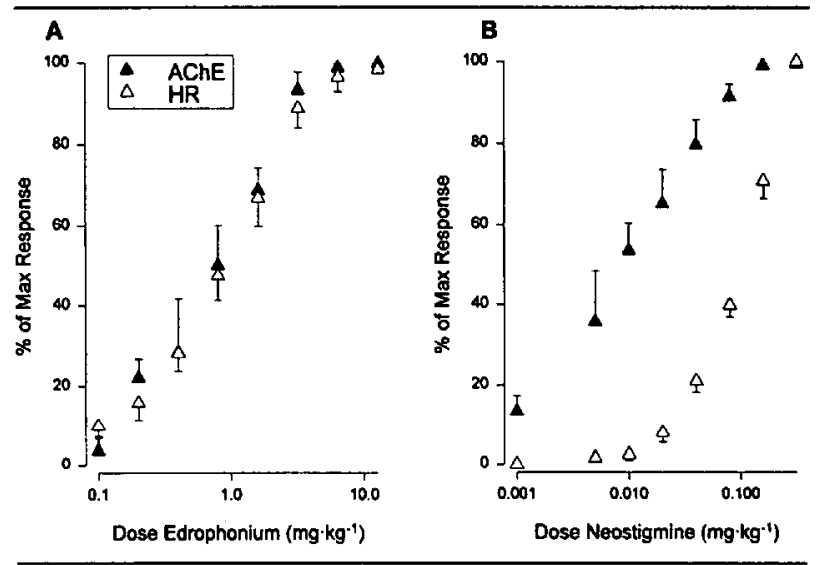

FIGURE 3 Relationship between the decrease in acetylcholinesterase activity (AChE) or heart rate (HR) expressed as percent of maximum response (ordinate) and dose of anticholinesterase (abscissa). Bars indicate S.E.M.

in heart rate was $22 \pm 2 \mathrm{bpm}(14.6 \pm 0.9 \%$ of baseline). The estimated dose of edrophonium which produced $50 \%$ of the maximum decrease in heart rate $(0.9 \pm 0.18$ $\mathrm{mg} \cdot \mathrm{kg}^{-1}$ ) was not different from that which produced $50 \%$ of the maximum decrease in cholinesterase activity $(P=0.6)$.

\section{Inhibition of cholinesterase activity and the bradycardia} produced by neostigmine

Neostigmine produced a dose-dependent decrease in cholinesterase activity ( $n=5$, Figures 2A, 3B) which reached a plateau when a cumulative dose of 0.16 $\mathrm{mg} \cdot \mathrm{kg}^{-1}$ had been administered. At the plateau, cholinesterase activity was inhibited by $93.4 \pm 1 \%$. 
Neostigmine also evoked a dose-dependent decrease in heart rate (Figures 2B and 3B). However, in contrast to the anticholinesterase effect which reached a plateau, the bradycardic effect did not taper off at higher doses. Heart rate decreased progressively with each additional dose of neostigmine until arrhythmias such as ectopic QRS complexes as well as third degree atrioventricular block were produced. ${ }^{3}$ At the lowest dose of neostigmine that produced maximal inhibition of cholinesterase activity $\left(0.16 \mathrm{mg} \cdot \mathrm{kg}^{-1}\right)$, heart rate decreased by $62.4 \pm$ $10.9 \mathrm{bpm}$, which represents $72.0 \pm 4 \%$ of the maximal decrease in heart rate with preservation of sinus rhythm produced by this agent. The maximal decrease in heart rate when the heart was still in sinus rhythm was produced by a dose of $0.32 \mathrm{mg} \cdot \mathrm{kg}^{-1}$. This dose caused a decrease in heart rate of $81 \pm 13 \mathrm{bpm}$ from a baseline value of $162 \pm 8 \mathrm{bpm}$ (decrease of $49 \pm 7 \%$ ). The doseresponse relationship for the bradycardic effect of neostigmine was shifted to the right of that for the inhibition of cholinesterase activity ( $n=5$, Figure 3B). For example, the estimated dose of neostigmine to produce $50 \%$ of the maximum bradycardia was $0.1 \pm 0.01$ $\mathrm{mg} \cdot \mathrm{kg}^{-1}$, approximately ten times that which produced a $50 \%$ reduction in cholinesterase activity $(0.009 \pm$ $0.003 \mathrm{mg} \cdot \mathrm{kg}^{-1}, P=0.0006$ ).

Muscarinic antagonism of the bradycardia produced by neostigmine and vagus nerve stimulation

Control heart rate prior to neostigmine administration (145 $\pm 4 \mathrm{bpm}, n=24$ ) was not different from that prior to vagus nerve stimulation ( $144 \pm 4 \mathrm{bpm}, n=23$ ). The dose-response curves of the muscarinic antagonists to block the neostigmine-induced bradycardia were shifted to the left compared with those of the antagonists to block the bradycardia produced by vagus nerve stimulation (Figures 4 and 5). The $\mathrm{ED}_{50} \mathrm{~s}$ of the non-selective muscarinic antagonists glycopyrrolate and atropine to block the bradycardia produced by "neostigmine was approximately one-half those required to block the bradycardia produced by vagus nerve stimulation (Table). The $\mathrm{ED}_{50} \mathrm{~s}$ of the selective $\mathrm{M}_{2}$.muscarinic receptor antagonists AFDX-116, pancuronium and gallamine to block the neostigmine-induced bradycardia were approximately one-half, one-quarter, and one-tenth of those required to block the bradycardia produced by vagus nerve stimulation, respectively (Table).

\section{Muscarinic antagonism of the bradycardia produced by edrophonium and vagus nerve stimulation}

Control heart rate prior to edrophonium administration (161 $\pm 7 \mathrm{bpm}, n=8$ ) was not different from that prior to vagus nerve stimulation (see above). The dose-response

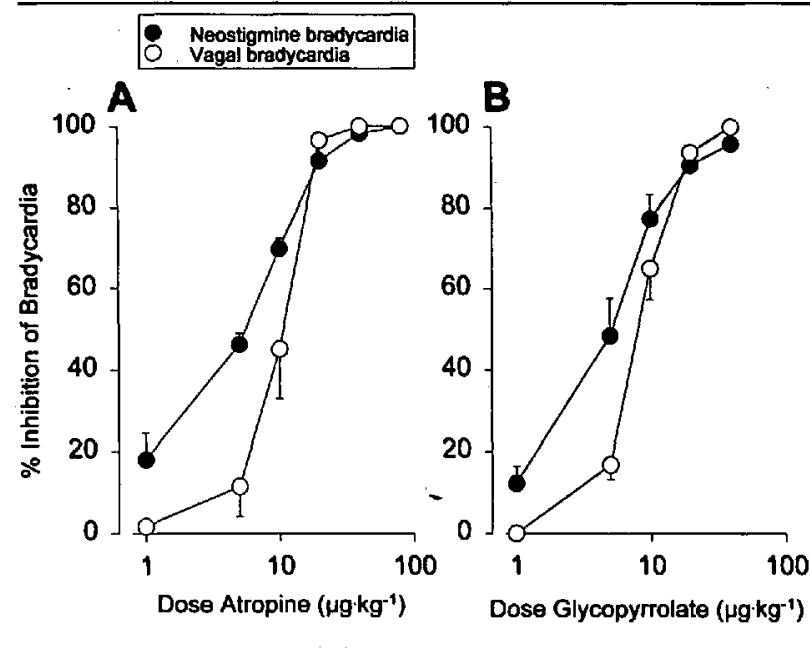

FIGURE 4 Relationship between dose of atropine (abscissa, panel A) or glycopyrrolate (abscissa, panel B) and percent inhibition of bradycardia (ordinate) evoked by neostigmine (filled circles) or by vagus nerve stimulation (open circles). Each point is the averaged response of four or five animals. Bars indicate S.E.M

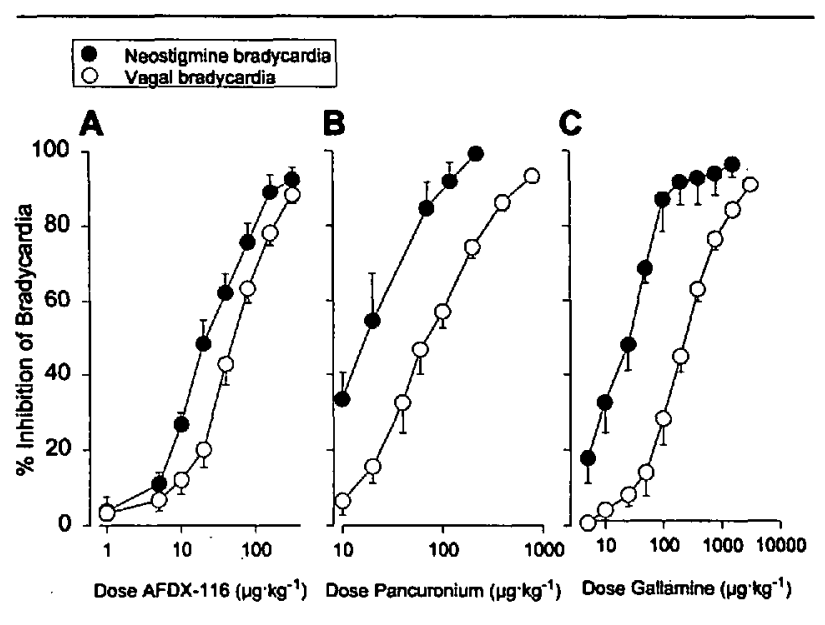

FIGURE 5 Relationship between dose of AFDX-1 16 (abscissa, panel A), pancuronium (abscissa, panel B) or gallamine (abscissa, panel C) and percent inhibition of bradycardia (ordinate) evoked by neostigmine (filled circles) or by vagus nerve stimulation (open circles). Each point is the averaged response of four to six animals. Bars indicate S.E.M.

curves of the muscarinic antagonists to block the edrophonium-induced bradycardia were similar compared with those of the antagonists to block the bradycardia produced by vagus nerve stimulation (Figure 6). The $\mathrm{ED}_{50} \mathrm{~s}$ for atropine and gallamine block of the edrophonium-induced bradycardia were not different from those for block of the bradycardia produced by vagus nerve stimulation (Table). Further studies using the other muscarinic antagonists to block the edrophonium-induced bradycardia were not done. 
TABLE Estimated doses $\left(\mu \mathrm{g} \cdot \mathrm{kg}^{-1}\right)$ of muscarinic receptor antagonists required to reverse by $50 \%$ the bradycardia produced by neostigmine $\left(0.25 \mathrm{mg} \cdot \mathrm{kg}^{-1}\right)$, edrophonium $\left(1.0 \mathrm{mg} \cdot \mathrm{kg}^{-1}\right)$ and vagus nerve stimulation $(10$ $\mathrm{V}, 0.5 \mathrm{msec}, 1-2 \mathrm{~Hz}, 10 \mathrm{sec})$.

\begin{tabular}{lllc}
\hline & Neostigmine & Edrophonium & Vagus stim \\
\hline $\mathrm{ED}_{50} \mathrm{Glyco}^{a}$ & $3.6 \pm 0.4 \dagger(n=4)$ & - & $8.6 \pm 0.4(n=5)$ \\
$\mathrm{ED}_{50}$ Atropine & $4.7 \pm 0.5 \dagger(n=5)$ & $10.2 \pm 3.1(n=4)$ & $9.8 \pm 1.2(n=4)$ \\
$\mathrm{ED}_{50}$ AFDX-116 & $30 \pm 6^{*}(n=5)$ & - & $55 \pm 9(n=4)$ \\
$\mathrm{ED}_{50}$ Panc $^{b}$ & $19 \pm 5 \dagger(n=6)$ & - & $80 \pm 15(n=5)$ \\
$\mathrm{ED}_{50} \mathrm{Gall}^{c}$ & $28 \pm 5 \ddagger(n=4)$ & $186 \pm 65(n=4)$ & $261 \pm 37(n=5)$ \\
\hline
\end{tabular}

${ }^{a}$ glycopyrrolate; ${ }^{b}$ pancuronium; ${ }^{c}$ gallamine.

$P$ values were determined from statistical comparison of $\mathrm{ED}_{50} \mathrm{~S}$ of muscarinic antagonists to reverse the bradycardia produced by antich'olinesterases vs vagus nerve stimulation.

$* P \leq 0.05, \dagger P \leq 0.01, \ddagger P \leq 0.001$.

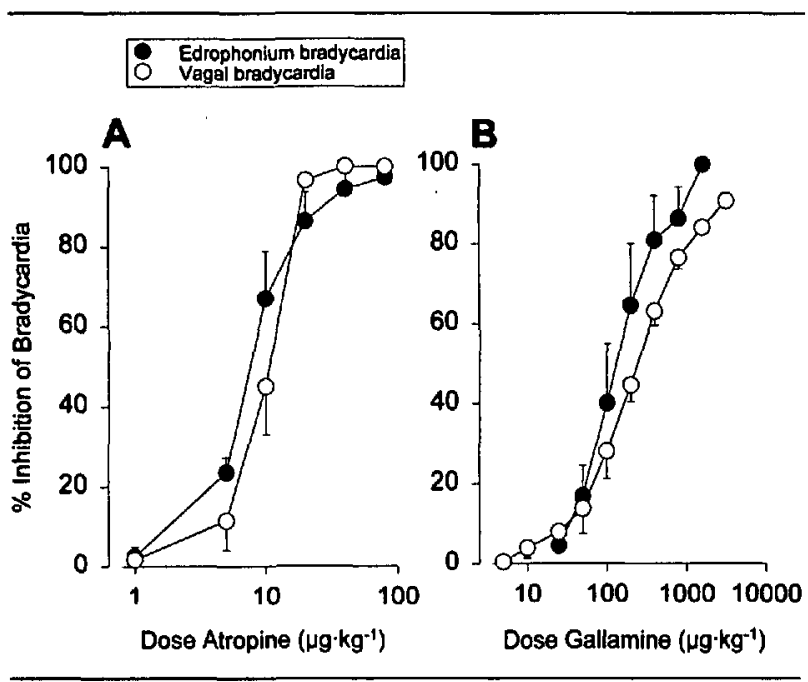

FIGURE 6 Relationship between dose of atropine (abscissa, panel A) or gallamine (abscissa, panel B) and percent inhibition of bradycardia (ordinate) evoked by edrophonium (filled circles) or by vagus nerve stimulation (open circles). Each point is the averaged response of four animals. Bars indicate S.E.M.

\section{Discussion}

In the present study, it was found that the shape of the dose-response curve of the bradycardia produced by neostigmine was strikingly different from that of the inhibition of cholinesterase activity. The dose-response relationship of the bradycardia was shifted to the right and the bradycardic effect did not reach a plateau even at doses well-beyond those at which the cholinesterase inhibition was maximal. In contrast, edrophonium produced dose-dependent decreases in cholinesterase activity and heart rate which were highly correlated, and the reduction in heart rate and cholinesterase activity reached a plateau with the same dose. Compared with the bradycardia produced by electrical stimulation of the vagus nerve, that produced by neostigmine was blocked by non-selective and selective $\mathbf{M}_{2}$ muscarinic antagonists at lower doses while that produced by edrophonium was blocked with similar doses. For edrophonium, the close association of depression of cholinesterase activity with reduction in heart rate is consistent with the hypothesis that it produces bradycardia by preventing hydrolysis of the $\mathrm{ACh}$ spontaneously released by axon terminals of cardiac parasympathetic neurones. The finding that the muscarinic antagonists block the bradycardia produced by edrophonium and that produced by vagus nerve stimulation at similar doses is also consistent with this hypothesis. In contrast, in the case of neostigmine, the lack of an association of the magnitude of the bradycardia with the inhibition of cholinesterase activity suggests that the anticholinesterase effect cannot account for the reduction in heart rate. Moreover, this conclusion is supported by the finding that the muscarinic antagonists block the bradycardia produced by neostigmine at significantly lower doses compared to the bradycardia produced by vagus nerve stimulation.

It is unlikely that these differences between neostigmine and edrophonium can be accounted for simply by their pharmacokinetic properties as they have previously been shown to be similar. ${ }^{7}$ Because the anticholinesterases were administered as bolus doses, rather than by continuous infusion, steady-state drug levels were not achieved. Nevertheless, since the object was to correlate two biological end-points, namely the reduction in heart rate and inhibition of cholinesterase activity, the actual drug levels were irrelevant. Interpretation of the findings in the present study may be complicated by the possibility that cholinesterase activity measured in erythrocytes does not reflect that in the heart. If this were the case, it could be argued that with neostigmine; higher doses were required to inhibit cholinesterase activity in the heart compared to that in red blood cells. While this possibility could theoretically account for the observation that the dose-response curve for the neostigmine- 
induced reduction in cholinesterase activity is shifted to the left of that for the reduction in heart rate (Figure 3B), it cannot account for the lack of a plateau in the magnitude of the neostigmine-induced bradycardia and for the much larger decreases in heart rate produced by neostigmine compared; to edrophonium (Figure 2B). In addition, this possibility seems' unlikely beeause of the findings with edrophonium, for which the close correlation between the magnitude of the inhibition of erythrocyte cholinesterase activity and bradycardia suggests that cholinesterase activity in the heart is inhibited by doses of anticholinesterase which are similar to those required to inhibit red cell cholinesterase.

Although there is no obvious relation between the reduction in cholinesterase activity and the bradycardia produced by neostigmine, it seems reasonable to assume that the anticholinesterase action of neostigmine is partly responsible: for producing at reduction in heart rate. This action may be estimated by comparing the bradycardic effects of neostigmine and edrophonium under conditions of similar cholinesterase inhibition, assuming that the bradycardia produced by edrophonium results entirely from its anticholinesterase action. The reduction in cholinesterase activity by approximately $80 \%$ provides a convenient reference point: In the case of edrophonium, when cholinesterase activity was reduced by this amount (which was the maximal effect) the heart rate decreased by $22 \pm 2 \mathrm{bpm}(14.6 \pm 0.9 \%$ of baseline $)$. When cholinesterase activity was reduced by the same amount by neostigmine, the decrease observed in heart rate was very similar ( $29 \pm 12 \mathrm{bpm}, 17 \pm 7 \%$ of baseline, $P=0.6$ ). This similar decrease in heart rate raises the possibility that up to the point when anticholinesterase activity is approximately $80 \%$ reduced; the effect of neostigmine, on heart rate may be accounted for by its anticholinesterase action. However, Figure 3. shows that for reductions in cholinesterase activity of $<80 \%$, a smaller bradycardic effect was observed with neostigmine compared to edrophonium. Thus, at present, it is difficult to determine to what extent the anticholinestertase action of neostigmine contributes to the reduction in heart rate.

Previously, we suggested that the neostigmineinduced bradycardia was mediated by $\mathrm{ACh}$, rather than by a direct action of neostigmine, on SA riode cells, based on the finding that the bradycardia was markedly attenuated following depletion of ACh stores in the cardiac parasympathetic pathway. ${ }^{3}$ Moreover, the neostigmine-evoked bradycardia was not diminished after degeneration of the parasympathetic preganglionic terminals, suggesting that the $\mathrm{ACh}$ was released by cardiac ganglion cells. We proposed that neostigmine activates excitatory cholinergic receptors on cardiac parasympa- thetic postganglionic cells, producing $\mathrm{ACh}$ release from their terminals and subsequent activation of inhibitory cardiac muscarinic receptors. ${ }^{3}$ Neostigmine was first suggested to act as a cholinergic agonist in cat skeletal muscle $^{8}$ and subsequent studies have indicated that it may behave as a cholinergic agonist at a variety of cholinoceptive sites, including mammalian autonomic ganglia. ${ }^{9-15}$

Regarding the identity of the cholinergic receptor activated by neostigmine, we have shown that the neostigmine-induced bradycardia is not blocked by selective nicotinic and muscarinic $M_{1}$ antagonists at doses consistent with activation of these receptor subtypes. ${ }^{3}$ Moreover, in studies using other models to investigate cardiac actions of cholinesterase inhibitors, it was demonstrated that neostigmine evokes the release of $\mathrm{ACh}$ from presumed cardiac parasympathetic neurones in the isolated chicken atrium, and that this effect was blocked by the non-selective muscarinic antagonist atropine but not by selective nicotinic and $M_{1}$ muscarinic receptor antagonists. ${ }^{4}$ The observation of excitatory effects mediated by $M_{2}$ muscarinic receptors in guinea-pig cardiac parasympathetic ganglion cells ${ }^{16}$ suggests the possibility that neostigmine produces its effect on heart rate by activating this type of receptor on cardiac parasympathetic postganglionic neurones. The demonstration of high levels of $m_{2}$ mRNA in rat parasympathetic cardiac ganglia ${ }^{17}$ is consistent with this possibility. It should be noted, however, that $\mathbf{M}_{2}$ muscarinic receptors are generally thought to mediate inhibitory actions. ${ }^{18}$

In the present study, the bradycardia produced by neostigmine was particularly sensitive to block by nonselective and selective $M_{2}$ muscarinic receptor antagonists when compared to that produced by vagus nerve stimulation, with doses ranging from one-half to onetenth. This range may reflect the fact that muscarinic antagonists exert different actions (e.g., release of neuroactive substances, inhibition of ionic channels) or bind to receptors in a different manner (e.g., at allosteric sites or at active sites competitively or non-competitively). ${ }^{6}$ Assuming that neostigmine produces bradycardia via activation of $\mathrm{M}_{2}$ muscarinic receptors on cardiac parasympathetic postganglionic neurones leading to subsequent release of $\mathrm{ACh}$ from their terminals, the greater sensitivity of the neostigmine-induced bradycardia to muscarinic block may be due to an additive blocking effect, resulting from an action of the muscarinic antagonist at both the cardiac ganglion cell and at the sinoatrial node (see Figure 1). Additionally, neostigmine may have a relatively weak affinity for muscarinic receptors on cardiac ganglion cells compared to endogenously-released ACh at the SA node. 
It can be argued that the greater potency of the $\mathrm{M}_{2}$ muscarinic receptor antagonists to block the bradycardia produced by neostigmine compared with that produced by vagus nerve stimulation is because neostigmine interacts with muscarinic receptors at the SA node and depresses their affinity for $\mathrm{ACh} .{ }^{19}$ This explanation is unlikely, however, because in such a situation, more $\mathrm{ACh}$ would be needed to obtain a given decrease in heart rate in the presence of neostigmine than in its absence. Since, in the present study, the magnitudes of the bradycardia produced by neostigmine and vagus nerve stimulation were similar any depression of $\mathrm{ACh}$ binding to the $\mathrm{M}_{2}$ muscarinic receptor in the presence of neostigmine must have been compensated by a greater ligand concentration. Moreover, the bradycardia produced by edrophonium (which has a similar displacing effect on binding of the muscarinic antagonist QNB as does neostigmine ${ }^{20}$ ) did not show a greater sensitivity to muscarinic receptor antagonists than the response to vagus nerve stimulation. Another possibility is that neostigmine binds to, and activates muscarinic receptors at the SA node. Due to possible heterogeneity of the muscarinic receptor population on SA node cells, ${ }^{21}$ the sets of receptors activated by the synaptically released agonist (vagal stimulation) and the blood borne agonist (neostigmine) may be different and have different affinity for $\mathrm{ACh}$ and/or for the agonists. However, our previous observation, discussed above, that the neostigmineinduced bradycardia is severely attenuated after depletion of $\mathrm{ACh}$ in the cardiac parasympathetic pathway argues against this possibility. ${ }^{3}$ In addition, it has been reported that neostigmine ${ }^{22}$ and other anticholinesterase $^{20}$ have an atropine-like effect when applied directly to atrial tissue leading to positive inotropy and chronotropy, an effect which is opposite to that observed in the present study.

In the present investigation, the bradycardia produced by anticholinesterases was studied in the absence of cardiac parasympathetic input (bilateral vagotomy). In patients with normal cardiac innervation, in which ACh is released from preganglionic and postganglionic neurons as a consequence of on-going vagus nerve activity, anticholinesterases may affect heart rate in a manner which is not analogous to that when there is no cardiac autonomic efferent input. This may account for the discrepancy of the findings in the present study, in which there is enhanced sensitivity of the neostigmine-induced bradycardia to muscarinic antagonism, with the clinical observation that less muscarinic antagonist is required to block the bradycardic effect of edrophonium ${ }^{23}$ than to block that of neostigmine. ${ }^{24}$ On the other hand, the experimental paradigm in the present study may be analogous to the effect of anticholinesterases on heart rate in patients who have undergone cardiac transplantation. Recently, we have shown that neostigmine ${ }^{25,26}$ and edrophonium ${ }^{27}$ evoke a reduction in heart rate in cardiac transplant patients and the findings of the present study may help to account for these observations.

An unexpected finding of the present study was that glycopyrrolate and atropine had similar potencies on a weight basis in their ability to block bradycardia produced by vagus nerve stimulation. It has been claimed that glycopyrrolate has a smaller effect on basal heart rate than that of atropine, based on clinical studies which were complicated by previous administration of drugs with muscarinic effects (e.g., atropine, pancuronium and anticholinesterases), varying depths of anaesthesia, or unequal doses of glycopyrrolate and atropine. ${ }^{28-33}$ Undoubtedly, the fact that glycopyrrolate is prepared as a $0.2 \mathrm{mg} \cdot \mathrm{ml}^{-1}$ solution whereas atropine is 0.6 $\mathrm{mg} \cdot \mathrm{ml}^{-1}$, further contributes to the clinical impression that glycopyrrolate is less potent than atropine on basal heart rate. It is important to realise that, in clinical studies which were more specifically designed to compare the effects of glycopyrrolate and atropine on basal heart rate, it has been shown that glycopyrrolate is at least as potent (if not more so) as atropine. ${ }^{34-39}$

In conclusion, the bradycardia produced by anticholinesterases may involve at least two mechanisms. One, exemplified by the response to edrophonium, is likely to involve only inhibition of cholinesterase. This bradycardia is highly correlated with the level of inhibition of cholinesterase, with the maximum decrease in heart rate occurring when cholinesterase activity is maximally inhibited. In addition, the bradycardia is blocked by muscarinic receptor antagonists at doses which are similar to those required to block the bradycardia produced by vagus nerve stimulation. A second mechanism, exemplified by neostigmine, is not clearly related to the level of cholinesterase activity such that even when cholinesterase activity is maximally inhibited, anticholinesterases continues to produce further reductions in the heart rate. This bradycardia is more sensitive to block by muscarinic receptor antagonists than is the bradycardia produced by vagus nerve stimulation.

\section{Acknowledgments}

We are grateful to Mr. L. Knafo and Ms. A. McNicol for expert technical assistance. We thank Boehringer Ingelheim Co. Ltd. for the generous supply of AFDX-116.

\section{References}

1 Hill $M$. Death after neostigmine injection (Letter). BMJ 1949; 2: 601.

2 Maclntosh $R R$. Death following injection of neostigmine. BMJ 1949; 1: 852. 
3 Backman SB, Bachoo M, Polosa C. Mechanism of the bradycardia produced in the cat by the anticholinesterase neostigmine. J Pharm Exp Ther 1993; 265: 194-200.

4 Brehm $G$, Lindmar $R$, Löffelholz $K$. Inhibitory and excitatory muscarinic receptors modulating the release of acetylcholine from the postganglionic parasympathetic neuron of the chicken heart. Naunyn Schmiedebergs Arch Pharmacol 1992; 346: 375-82.

5 Brown JH, Taylor $P$. Muscarinic receptor agonists and antagonists. In: Hardman JG, Limbird LE, Molinoff PB, Ruddon R.W, Gilman AG (Eds.).Goodman \& Gilman's The Pharmacological Basis of Therapeutics, 9th ed New York: McGraw-Hill, 1996: 141-60.

6 Mitchelson $F$. Muscarinic receptor differentiation. Pharmacol Ther 1988; 37: 357-423.

7 Morris RB, Cronnelly R, Miller RD, Stanski DR, Fahey $M R$. Pharmacokinetics of edrophonium and neostigmine when antagonizing $d$-tubocurarine neuromuscular blockade in mart. Anesthesiology 1981; 54: 399-402.

8 Riker WF Jr, Wescoe WC. The direct action of prostigmine on skeletal muscle; its relationship to the choline esters. J Pharmacol Exp Ther 1946; 88: 58-66.

9 Pascoe JE. The effects of acetylcholine and other drugs on the isolated superior cervical ganglion. J Physiol 1956; 132: 242-55.

10 Long JP, Eckstein JW. Ganglionic actions of neostigmine methylsulfate. J Pharmacol Exp Ther 1961; 133: 216-22.

11 Mason DFJ. A ganglion stimulating action of neostigmine. Br J Pharmacol 1962; 18: 76-86.

12 Mason DFJ. Depolarizing action of neostigmine at an autonomic ganglion. Br J Pharmacol 1962; 18: 572-87.

13 Carlyle RF. The mode of action of neostigmine and physostigmine on the guinea-pig trachealis muscle. $\mathrm{Br} \mathbf{J}$ Pharmacol 1963; 21: 137-49.

14 Takeshige C, Volle RL. Asynchronous postganglionic firing from the cat superior cervical sympathetic ganglion treated with neostigmine. Br J Pharmacol 1963; 20 : 214-20.

15 Kostowski W, Gumutka W. Actions of neostigmine and physostigmine on sympathetic ganglia in the cat. International Journal of Neuropharmacology 1966; 5 : 193-8.

16 Mihara S, lkeda $K$, Nishi $S$. Muscarinic M2 receptors on cardiac ganglion neurons of the guinea-pig heart. Kurume Med J 1988; 35: 183-92.

17 Hoover DB, Baisden RH, Xi-Moy SX. Localization of muscarinic receptor mRNAs in rat heart and intrinsic cardiac ganglia by in situ hybridization. Circ Res 1994; 75 : 813-20.

18 Allen TGJ, Burnstock G. $\mathrm{M}_{1}$ and $\mathrm{M}_{2}$ muscarinic receptors mediate excitation and inhibition of guinea-pig intracardiac neurons in culture. J Physiol 1990; 422: 463-80.

19 Dunlap J, Brown JH. Heterogeneity of binding sites on cardiac muscarinic receptors induced by the neuromuscular blocking agents gallamine and pancuronium. Mol Pharmacol 1983; 24: 15-22.

20 Brown JH, Wetzel GT, Dunlap J. Activation and blockade of cardiac muscarinic receptors by endogenous acetylcholine and cholinesterase inhibitors. J Pharm Exp Ther 1982; 223: 20-4.

21 Campbell GD, Edwards FR, Hirst GDS, O'Shea JE. Effects of vagal stimulation and applied acetylcholine on pacemaker potentials in the guinea-pig heart. J Physiol 1989; 415: 57-68.

22 De Wildt DJ, Oud PHJH, Porsius AJ. The inotropic and chronotropic effects of physostigmine and neostigmine on guinea-pig isolated atria. J Auton Pharmacol 1982; 2: 111-7.

23 Cronnelly $R$, Morris $R B$, Miller RD. Edrophonium: duration of action and atropine requirement in humans during halothane anesthesia. Anesthesiology 1982; 57: 261-6.

24 Fogdall RP, Miller RD. Antagonism of $d$-tubocurarineand pancuronium- induced neuromuscular blockades by pyridostigmine in man. Anesthesiology 1973; 39: 504-9.

25 Backman, SB, Fox, GS, Stein, RD, Ralley, FE. Neostigmine decreases heart rate in heart transplant patients. Can J Anaesth 1996; 43: 373-8.

26 Backman SB, Ralley FE, Fox GS. Neostigmine produces bradycardia in a heart transplant patient. Anaesthesiology 1993; 78: 777-9.

27 Backman SB, Stein RD, Fox GS, Polosa C. Effect of edrophonium on heart rate in cardiac transplant patients and in the denervated cat heart. Can.J Anaesth 1996; 43: (in press).

28 Ramamurthy S, Ylagan LB, Winnie AP. Glycopyrrolate as a substitute for atropine: a preliminary report. Anesth Analg 1971; 50: 732-6.

29 Mirakhur RK, Dundee JW, Clarke RSJ. Glycopyrrolateneostigmine mixture for antagonism of neuromuscular block: comparison with atropine-neostigmine mixture. $\mathrm{Br}$ J Anaesth 1977; 49: 825-9.

30 Salem MG, Richardson JC, Meadows GA, Lamplugh G, Lai KM. Comparison between glycopyrrolate and atropine in a mixture with neostigmine for reversal of neuromuscular blockade. Br J Anaesth 1985; 57: 184-7.

31 Orduro KA. Glycopyrrolate methobromide. 2. Comparison with atropine sulphate in anaesthesia. Can Anaesth Soc J 1975; 22: 466-73.

32 Ostheimer $G W$. A comparison of glycopyrrolate and atropine during reversal of nondepolarizing neuromuscular block with neostigmine. Anesth Analg 1977; 56: 182-6.

33 Meyers EF, Tomeldan SA. Glycopynolate compared with atropine in prevention of the oculocardiac reflex during eye-muscle surgery. Anesthesiology 1979; 51: 350-2.

34 Mirakhur RK, Dundee JW, Jones CJ, Coppel DL, Clarke $R S J$. Reversal of neuromuscular blockade: dose determi- 
nation studies with atropine and glycopyrrolate given before or in a mixture with neostigmine. Anesth Analg 1981; 60: 557-62.

35 Abboud T, Raya J, Sadri S, Grobler N, Stine L, Miller F. Fetal and maternal cardiovascular effects of atropine and glycopyrrolate. Anesth Analg 1983; 62: 426-30.

36 Preiss $D$, Berguson $P$. Dose-response studies on glycopyrrolate and atropine in conscious cardiac patients. $\mathrm{Br} \mathrm{J}$ Clin Pharmacol 1983; 16: 523-7.

37 Berger J, Gravenstein J, van der Aa J, Paulus L, SabahMaren E, McLaughlin G. Comparative potency of atropine sulphate and glycopyrrolate on heart rate in man. Eur J Anaesthesiol 1988; 5: 23-30.

38 Green DW, Bristow ASE, Fisher $M$. Comparison of i.v. glycopyrrolate and atropine in the prevention of bradycardia and arrhythmias following repeated doses of suxamethonium in children. Br J Anaesth 1984; 56: 981-4.

39 Ali-Melkkila T, Kaila T, Antila K, Halkola L, Iisalo E. Effects of glycopyrrolate and atropine on heart rate variability. Acta Anaesthesiol Scand 1991; 35: 436-41. 